\title{
INFLUENCE OF DIFFERENT SIZES OF BROODING BOX MADE OF CLAY AND BAMBOO BASKET ON THE HATCHABILITY OF CHICKEN EGGS THROUGH BROODY HEN
}

\author{
M. S. Islam, M. M. Sarkar ${ }^{1}$, M. J. Uddin ${ }^{1}$ and A. R. Howlider \\ ${ }^{1}$ Department of Poultry Science, Bangladesh Agricultural University \\ Mymensingh-2202, Bangladesh
}

\begin{abstract}
An experiment was conducted to hatch chicken eggs in two different types of brooding boxes made of clay and bamboo basket by using broody hen. Three different size boxes were used under each type which were large $(48 \times 33 \times 18 \mathrm{~cm})$, medium $(43 \times 28 \times 18 \mathrm{~cm})$ and small $(38 \times 23 \times 18 \mathrm{~cm})($ i.e. diameter of upper portion $\times$ diameter of lower portion $\times$ height of brooding boxes). The objective was to identify the optimum size of the brooding box used for natural hatching and to identify the appropriate material for brooding box used for incubation of eggs under rural condition. The fertility was not significantly affected by the type and size of boxes. Hatchability, Chicks not pipped and dead in germ were not significantly affected by types of boxes made of clay and bamboo basket but significantly affected by the size of boxes $(p<0.05)$. The dead in shell was significantly affected by types and sizes of brooding box made of clay and bamboo basket $(p<0.05)$. The percentage of dead in shell increased with the decreasing size of brooding box. Finally, it was concluded that hatchability of Deshi chicken eggs incubated by broody hen can be affected by both materials and size of brooding box. The study has shown that hatchability increased with increased size of the box up to a certain level. On the other hand, clay box gives more hatchability than bamboo basket.
\end{abstract}

Key Words : Brooding box, Hatchability, Broody hen

\section{INTRODUCTION}

About $78 \%$ of poultry eggs and $86 \%$ of poultry meat are produced by smallholder farmers under scavenging system (Latif, 1999) however in the recent years commercial poultry production in private sector is expanding rapidly in Bangladesh. Egg production of native chicken is 35 to 45 eggs per year (Bulbul et al., 1983). However, Khan (1983) found that the native fowl lays 50-80 eggs per year on average. The size of hens and number of eggs set under each hen might influence the hatchability of eggs and subsequent successful rearing of chicks (Haque et al., 1991). The broody hens perform a traditional hatching of eggs for small rural industry. Variability in the number of eggs set, management faults, etc. might adversely affect hatchability of eggs under natural brooding system. Natural brooding system is less expensive but produces fewer chicks. If

\footnotetext{
${ }^{1}$ Biotechnology Division, Bangladesh Livestock Research Institute, Savar, Dhaka-134, Bangladesh
} 
we allow several hens to brood a clutch at the same time, we may need additional nests to accommodate the hens in lay. Besides, sufficiency of nest or brooding box of standard size many also play an important role in hatchability of eggs. Thus the present investigation was designed to identify the optimum size of the brooding box used for natural hatching and to identify the appropriate material for brooding box in rural area.

\section{MATERIALS AND METHODS}

The experiment was conducted at the house of farmers in the three villages of Noakhali Sadar Upazilla under the project area of the Smallholder Livestock Development Project2 for a period of 45 days.

Preparation of brooding boxes : Two types of brooding boxes such as clay and bamboo with three different sizes under each type were made. The sizes were large $(48 \times 33 \times 18$ $\mathrm{cm}),(43 \times 28 \times 18 \mathrm{~cm})$ and $(38 \times 23 \times 18 \mathrm{~cm})$ [i.e. diameter of upper portion $\times$ diameter of lower portion $\times$ height of brooding boxes].

Selection and collection of broody hens : The native chickens at the end of egg production of current laying cycle and experienced at least one hatch but not more than three hatches were selected and purchased for experimental purpose. The broody hens chosen for natural incubation were large, healthy and with a good brooding and mothering record.

Age of the broody hen : Hens above 1 year of age were used for the experimental purpose.

Selection of farmers : Eighteen farmers were selected randomly from village of the project area particularly who are experienced in natural hatching.

Collection of hatching eggs : The fertile eggs of average size with more or less similar in weight were purchased from the farmers of the project area. Eggs are collected only from those household who have the cock for mating to ensure the fertility of eggs.

Selection and care of hatching eggs : After collection, eggs were selected on the basis of their size, shape, and cleanliness. The Average size of the eggs was $36.30 \pm 2.20 \mathrm{~g}$.

\section{Preparation of broody hens}

Control of ecto-parasites : the hens were thoroughly dusted 4 days prior to setting with Neguvon $(0.3 \%)$ mixed with ash to make the hens free from lice and other ectoparasites. If lice appeared on any chicken during incubation, liquid Ivomec was also used by applying 2 drops on the neck of the hen. Prior to set the eggs the broody hens were also treated by medicine available in the local markets such as symen vet. for lice infestation.

Setting of eggs under broody hens : The selected eggs of 20 were set under the broody hen in each brooding box. Prior to set the brooding boxes were filled with 4 inches with 
ashes. Over the ashes fine soft straw was placed and latter pressed down to make a hollow. The eggs were placed in the hollow. The hen was gently seated on them and left undisturbed. The nest with the hen was kept in a quiet corner usually under the bed. The eggs were set under the hen at evening time as she was more likely to settle down to her job.

Management of hens during incubation : After setting an $0.5 \%$ melathion powder was sprinkled over the nesting material. Dry, clean and well ventilated place was considered for hatching egg. Proper feeding and watering facilities were provided for them to ensure better supplement of heat for hatching eggs. The hens were observed frequently through out the incubation period. The body weight of broody hens was taken at least once per week. Feed and water provided in close proximity to the hen.

Candling of the eggs : All the eggs were removed from the broody's nest and a strong light was shined through each egg. The eggs which were viable, a spider web of blood vessels supporting the growing embryo and at the center of the web, the embryo was found. It was rather small at this stage. An egg lacking embryos which show nothing but the outline of the yolk or a dark floating mass. Such eggs were discarded.

Record keeping : Egg number per hen, egg weight, initial weight of hen, number of eggs culled after candling, chick hatched, chick not hatched, embryonic mortality, chick weight, final weight of hen after hatching and body weight loss of hen parameters were recorded.

Fertility : The fertility was determined by candling eggs on the 10 day of incubation by a torch light in a dark room and the eggs showing blood vessels were considered as clean eggs and also another. Candling was also done on the $14^{\text {th }}$ day of incubation to identify the growing embryos. Fertility of eggs was calculated by using the following formula-

$$
\text { Fertility }(\%)=\frac{\text { Total number of fertile eggs }}{\text { Total number of eggs set }} \times 100
$$

Hatchability : The chicks come out of the shell on $21^{\text {st }}$ day of incubation were recorded as hatched chicks. Hatchability of eggs was calculated on the basis of egg set and on the basis of fertile eggs. The hatchability on eggs set and on fertile eggs was calculated by the following formulae.

$$
\begin{aligned}
& \text { Hatchability on eggs set }(\%)=\frac{\text { Total number of chicks hatched }}{\text { Total number of eggs set }} \times 100 \\
& \text { Hatchability on fertile eggs }(\%)=\frac{\text { Total number of chicks hatched }}{\text { Total number of fertile eggs }} \times 100
\end{aligned}
$$

Dead-in-shell : The unhatched eggs were broken out to conform age of the dead embryos in shell. 
Pipped chicks : The chicks that pipped but did not come out of the shell were considered as pipped chicks.

Chicks not pipped : Embryonic mortality was calculated by the following formula-

Embryonic mortality $(\%)=\frac{\text { Total number of dead embryos }}{\text { Total number of fertile eggs }} \times 100$

Layout of the experiment : The experiment was conducted using 18 broody hens with 20 eggs under each hen. Eighteen brooding boxes with two types and three sizes were used for hatching. Each type $\times$ size combination had 3 replications. Twenty clean and sound eggs were incubated under each hen.

Layout of the experiment : The experiment was conducted using 18 broody hens with 20 eggs under each hen. Eighteen brooding boxes with two types and three sizes were used for hatching. Each type $\times$ size combination had 3 replications. Twenty clean and sound eggs were incubated under each hen.

Table 1. Layout of the experiment

\begin{tabular}{l|cccc}
\hline \multirow{2}{*}{ Type } & \multirow{2}{*}{ Replication } & \multicolumn{3}{|c}{ No. of eggs per brooding box } \\
\cline { 3 - 5 } & & $(48 \times 33 \times 18) \mathrm{cm}\left(\mathrm{S}_{1}\right)$ & $(43 \times 28 \times 18) \mathrm{cm}\left(\mathrm{S}_{2}\right)$ & $(38 \times 23 \times 18) \mathrm{cm}\left(\mathrm{S}_{3}\right)$ \\
\hline $\mathrm{M}_{1}$ & $\mathrm{R}_{1}$ & 20 & 20 & 20 \\
& $\mathrm{R}_{2}$ & 20 & 20 & 20 \\
& $\mathrm{R}_{3}$ & 20 & 20 & 20 \\
\hline $\mathrm{M}_{2}$ & $\mathrm{R}_{1}$ & 20 & 20 & 20 \\
& $\mathrm{R}_{2}$ & 20 & 20 & 20 \\
& $\mathrm{R}_{3}$ & 20 & 20 & 20 \\
\hline
\end{tabular}

Note : $\mathrm{M}_{1}=$ Material 1 (Clay), $\mathrm{M}_{2}=$ Material 2 (Bamboo basket); $\mathrm{S}_{1}=$ Size 1 (Large), $\mathrm{S}_{2}=$ Size 2(Medium), $S_{3}=$ Size 3 (Small); $R_{1}=$ Replication 1, $R_{2}=$ Replication 2, $R_{3}=$ Replication 3

Data analysis : Data analysis was performed by SPSS- 11.5 for windows software.

\section{RESULTS}

Fertility : The effect of three different sizes of brooding boxes made of clay and bamboo basket on fertility is shown in the Table 2 . Fertility was not significantly affected by types of boxes made of clay $\mathrm{M}_{1}$ and bamboo basket $\mathrm{M}_{2}$. Fertility obtained for clay box were $98.33,96.66$ and $98.33 \%$ for three different sizes large $\left(\mathrm{S}_{1}\right)$, medium $\left(\mathrm{S}_{2}\right)$ and small $\left(\mathrm{S}_{3}\right)$ respectively and that for bamboo basket were 96.66 , and 93.33 and $96.66 \%$ respectively. On the other hand, the fertility was not also significantly affected by the size of brooding boxes and the results were same. 
Table 2. Fertility (\%) obtained by incubating eggs in three different sizes of brooding boxes made of clay and bamboo basket

\begin{tabular}{|c|c|c|c|c|}
\hline \multirow[t]{3}{*}{ Type } & \multirow[t]{3}{*}{ Replication } & \multicolumn{3}{|c|}{ Size $(\mathrm{cm})$} \\
\hline & & $48 \times 33 \times 18$ & $43 \times 28 \times 18$ & $38 \times 23 \times 18$ \\
\hline & & $\mathrm{T}_{1}$ & $\mathrm{~T}_{2}$ & $\mathrm{~T}_{3}$ \\
\hline \multirow[t]{5}{*}{ Clay } & $\mathrm{R}_{1}$ & 95 & 90 & 100 \\
\hline & $\mathrm{R}_{2}$ & 100 & 100 & 95 \\
\hline & $\mathrm{R}_{3}$ & 100 & 100 & 100 \\
\hline & Mean & 98.33 & 96.67 & 98.33 \\
\hline & SD & 2.88 & 5.77 & 2.88 \\
\hline \multirow[t]{5}{*}{ Bamboo basket } & $\mathrm{R}_{1}$ & 95 & 95 & 90 \\
\hline & $\mathrm{R}_{2}$ & 100 & 95 & 100 \\
\hline & $\mathrm{R}_{3}$ & 95 & 90 & 100 \\
\hline & Mean & 96.67 & 93.33 & 96.67 \\
\hline & SD & 2.88 & 2.88 & 5.77 \\
\hline
\end{tabular}

Hatchability : Hatchability was not significantly affected by two types of boxes made of clay $\mathrm{M}_{1}$ and bamboo basket $\mathrm{M}_{2}$. Hatchability obtained for the eggs incubated in the clay box were $98.33,86.66$ and $81.33 \%$ for three different sizes i.e. large, medium and small respectively and that for bamboo basket were 100.00 , and 87.00 and $74.66 \%$ respectively (Table 3). The hatchability was significantly differ by the size of brooding boxes made of clay and bamboo basket $(\mathrm{p}<0.05)$ but the results were same.

Table 3. Hatchability (\%) (Fertile egg basis) obtained by incubating eggs in three different sizes of brooding boxes made of clay and bamboo basket

\begin{tabular}{l|l|c|c|c}
\hline \multirow{2}{*}{ Type } & Replication & \multicolumn{3}{|c}{ Size $(\mathrm{cm})$} \\
\cline { 3 - 5 } & & $48 \times 33 \times 18$ & $43 \times 28 \times 18$ & $38 \times 23 \times 18$ \\
\cline { 3 - 5 } Clay & $\mathrm{R}_{1}$ & $\mathrm{~T}_{1}$ & $\mathrm{~T}_{2}$ & $\mathrm{~T}_{3}$ \\
\cline { 2 - 5 } & $\mathrm{R}_{2}$ & 100 & 100 & 90 \\
& $\mathrm{R}_{3}$ & 100 & 80 & 79 \\
\cline { 2 - 5 } & Mean & 95 & 80 & 75 \\
\cline { 2 - 5 } & $\mathrm{SD}$ & 98.33 & 86.67 & 81.33 \\
\hline \multirow{3}{*}{ Bamboo basket } & $\mathrm{R}_{1}$ & 100 & 11.54 & 8.77 \\
& $\mathrm{R}_{2}$ & 100 & 89 & 65 \\
& $\mathrm{R}_{3}$ & 100 & 89 & 70 \\
\cline { 2 - 5 } & Mean & 100 & 87.00 & 74.67 \\
\cline { 2 - 5 } & $\mathrm{SD}$ & 0.00 & 3.46 & 12.66 \\
\hline
\end{tabular}


Chicks not pipped : There was no significant difference among the not pipped chicks hatched by clay and bamboo types of brooding. The average Chicks not pipped obtained were $1.66,13.33$ and $18.66 \%$ for the eggs hatched in the clay boxes of large, medium and small respectively and that for bamboo basket were $0.00,12.55$ and $25.37 \%$ respectively. But the Chicks not pipped were significantly affected by sizes of brooding box made of clay and bamboo basket $(p<0.05)$. The percentage of Chicks not pipped was increased with the decreasing of size of brooding boxes for both clay and bamboo basket. The result is shown in the table 4 .

Table 4. Chicks not pipped (\%) obtained by incubating eggs in three different sizes of brooding boxes made of clay and bamboo basket

\begin{tabular}{l|l|c|c|c}
\hline \multirow{2}{*}{ Type } & \multirow{2}{*}{ Replication } & \multicolumn{3}{|c}{ Size $(\mathrm{cm})$} \\
\cline { 3 - 5 } & & $48 \times 33 \times 18$ & $43 \times 28 \times 18$ & $38 \times 23 \times 18$ \\
\cline { 3 - 5 } Clay & $\mathrm{R}_{1}$ & $\mathrm{~T}_{1}$ & $\mathrm{~T}_{2}$ & $\mathrm{~T}_{3}$ \\
\cline { 3 - 5 } & $\mathrm{R}_{2}$ & 0.00 & 0.00 & 10.00 \\
& $\mathrm{R}_{3}$ & 0.00 & 20.00 & 21.00 \\
\cline { 2 - 5 } & Mean & 5.00 & 20.00 & 25.00 \\
\cline { 2 - 5 } & $\mathrm{SD}$ & 1.67 & 13.33 & 18.66 \\
\hline Bamboo basket & $\mathrm{R}_{1}$ & 0.00 & 11.55 & 7.77 \\
& $\mathrm{R}_{2}$ & 0.00 & 10.50 & 11.11 \\
& $\mathrm{R}_{3}$ & 0.00 & 10.50 & 35.00 \\
\cline { 2 - 5 } & Mean & 0.00 & 16.66 & 30.00 \\
\cline { 2 - 5 } & $\mathrm{SD}$ & 0.00 & 3.55 & 12.55 \\
\hline
\end{tabular}

Dead in germ : The dead in germ was not significantly affected by types of brooding box made of clay and bamboo basket. The average dead in germ obtained were 1.66, 8.33 and $8.60 \%$ for clay boxes for large $\left(\mathrm{S}_{1}\right)$, medium $\left(\mathrm{S}_{2}\right)$ and small $\left(\mathrm{S}_{3}\right)$ respectively and that for bamboo basket were $0.00,8.85$ and $6.66 \%$ respectively.

But the dead in germ was significantly affected by sizes of brooding box made of clay and bamboo basket $(\mathrm{p}<0.05)$. The percentage of dead in germ increase with the decreasing size of brooding box of both clay and bamboo basket. The result is shown in the Table 5 .

Dead in shell : The dead in shell was significantly affected by types and sizes of brooding box made of clay and bamboo basket $(p<0.05)$. The average dead in germ obtained were $0.00,5.00$ and $10.08 \%$ for clay boxes for large $\left(S_{1}\right)$, medium $\left(S_{2}\right)$ and small $\left(\mathrm{S}_{3}\right)$ respectively (Table 6) and that for bamboo basket were $0.00,3.70$ and $18.70 \%$ respectively. The dead in shell increase with the decreasing size of brooding box. 
Table 5. Dead in germ (\%) obtained by incubating eggs in three different sizes of brooding boxes made of clay and bamboo basket

\begin{tabular}{|c|c|c|c|c|}
\hline \multirow[t]{3}{*}{ Type } & \multirow[t]{3}{*}{ Replication } & \multicolumn{3}{|c|}{ Size $(\mathrm{cm})$} \\
\hline & & $48 \times 33 \times 18$ & $43 \times 28 \times 18$ & $38 \times 23 \times 18$ \\
\hline & & $\mathrm{T}_{1}$ & $\mathrm{~T}_{2}$ & $\mathrm{~T}_{3}$ \\
\hline \multirow[t]{5}{*}{ Clay } & $\mathrm{R}_{1}$ & 0.00 & 0.00 & 0.00 \\
\hline & $\mathrm{R}_{2}$ & 0.00 & 15.00 & 15.78 \\
\hline & $\mathrm{R}_{3}$ & 5.00 & 10.00 & 10.00 \\
\hline & Mean & 1.67 & 8.33 & 8.60 \\
\hline & $\mathrm{SD}$ & 2.88 & 7.64 & 7.98 \\
\hline \multirow[t]{5}{*}{ Bamboo basket } & $\mathrm{R}_{1}$ & 0.00 & 10.50 & 0.00 \\
\hline & $\mathrm{R}_{2}$ & 0.00 & 10.50 & 10.00 \\
\hline & $\mathrm{R}_{3}$ & 0.00 & 5.55 & 10.00 \\
\hline & Mean & 0.00 & 8.85 & 6.67 \\
\hline & SD & 0.00 & 2.85 & 5.77 \\
\hline
\end{tabular}

Table 6. Dead in shell (\%) obtained by incubating eggs in three different sizes of brooding boxes made of clay and bamboo basket

\begin{tabular}{|c|c|c|c|c|}
\hline \multirow[t]{3}{*}{ Type } & \multirow[t]{3}{*}{ Replication } & \multicolumn{3}{|c|}{ Size $(\mathrm{cm})$} \\
\hline & & $48 \times 33 \times 18$ & $43 \times 28 \times 18$ & $38 \times 23 \times 18$ \\
\hline & & $\mathrm{T}_{1}$ & $\mathrm{~T}_{2}$ & $\mathrm{~T}_{3}$ \\
\hline \multirow[t]{5}{*}{ Clay } & $\mathrm{R}_{1}$ & 0.00 & 0.00 & 10.00 \\
\hline & $\mathrm{R}_{2}$ & 0.00 & 5.00 & 5.26 \\
\hline & $\mathrm{R}_{3}$ & 0.00 & 10.00 & 15.00 \\
\hline & Mean & 0.00 & 5.00 & 10.08 \\
\hline & SD & 0.00 & 5.00 & 4.87 \\
\hline \multirow[t]{5}{*}{ Bamboo basket } & $\mathrm{R}_{1}$ & 0.00 & 0.00 & 11.11 \\
\hline & $\mathrm{R}_{2}$ & 0.00 & 0.00 & 25 \\
\hline & $\mathrm{R}_{3}$ & 0.00 & 11.11 & 20 \\
\hline & Mean & 0.00 & 3.70 & 18.70 \\
\hline & SD & 0.00 & 6.41 & 7.03 \\
\hline
\end{tabular}

Comparison between clay and bamboo types of boxes with respect to fertility, hatchability, chicks not pipped, dead in germ and dead in shell

Comparison between clay and bamboo types of boxes with respect to fertility, hatchability, chicks not pipped, dead in germ and dead in shell are shown in table 7 . We 
raised the question whether clay box or bamboo box is better for hatching egg in terms of fertility, hatchability, embryonic mortality and chick weight. It was found that the fertility was higher for clay box $(98.33,96.67$ and $95.00 \%)$ than bamboo box $(96.67,93.33$ and $96.67 \%$ ). Hatchability on the basis of fertile egg was higher in case of clay box (98.33, 86.67 and $84.67 \%)$ than bamboo box $(93.58,87.00$ and $74.67 \%)$. Embryonic mortality was slightly higher in case bamboo box $(1.67,1.33$ and $0.00 \%)$ than clay box $(0.33,1.00$ and $1.00 \%$ ).

Table 7. Comparison between clay and bamboo types of boxes in the aspect of fertility, hatchability, chicks not pipped, dead in germ and dead in shell

\begin{tabular}{llc|c|c}
\hline \multirow{2}{*}{ Parameters } & \multicolumn{3}{c}{ Box Size $(\mathrm{cm})$} \\
\cline { 3 - 5 } & & $48 \times 33 \times 18 \mathrm{~cm}$ & $43 \times 28 \times 18 \mathrm{~cm}$ & $38 \times 23 \times 18 \mathrm{~cm}$ \\
\hline Fertility (\%) & Clay & $98.33^{\mathrm{a}}$ & $96.66^{\mathrm{a}}$ & $98.33^{\mathrm{a}}$ \\
& Bamboo basket & $96.66^{\mathrm{a}}$ & $93.33^{\mathrm{a}}$ & $96.66^{\mathrm{a}}$ \\
\hline Hatchability (\%) & Clay & $98.33^{\mathrm{a}}$ & $86.66^{\mathrm{a}}$ & $81.33^{\mathrm{b}}$ \\
& Bamboo basket & $100.00^{\mathrm{a}}$ & $87.00^{\mathrm{a}}$ & $74.66^{\mathrm{b}}$ \\
\hline Chicks not pipped (\%) & Clay & $1.66^{\mathrm{a}}$ & $13.33^{\mathrm{a}}$ & $18.66^{\mathrm{b}}$ \\
& Bamboo basket & $0.00^{\mathrm{a}}$ & $12.55^{\mathrm{a}}$ & $25.37^{\mathrm{b}}$ \\
\hline Dead in germ (\%) & Clay & $1.66^{\mathrm{a}}$ & $8.33^{\mathrm{a}}$ & $8.56^{\mathrm{b}}$ \\
& Bamboo basket & $0.00^{\mathrm{a}}$ & $8.85^{\mathrm{a}}$ & $6.66^{\mathrm{b}}$ \\
\hline Dead in shell (\%) & Clay & $0.00^{\mathrm{a}}$ & $5.00^{\mathrm{a}}$ & $10.08^{\mathrm{b}}$ \\
& Bamboo basket & $0.00^{\mathrm{a}}$ & $3.70^{\mathrm{a}}$ & $18.70^{\mathrm{b}}$ \\
\hline
\end{tabular}

Figures in the rows and columns having similar alphabet do not differ significantly

\section{Correlations among different hatchability traits of the eggs hatched in the clay box}

Correlations among different hatchability traits of the eggs hatched in the clay box are shown in table 8. Positive and non-significant correlations were found between fertility and chicks not pipped, dead in germ and dead in shell. But correlation between fertility and hatchability both on total eggs set and fertility egg basis was negative and nonsignificant.

Hatchability on total egg set was positively and significantly correlated with hatchability on fertile egg set $(\mathrm{p}<0.01)$. Hatchability on total egg set was negatively and significantly correlated with chicks not pipped, dead in germ $(\mathrm{p}<0.01)$ \& dead in shell $(\mathrm{p}<0.05)$. The correlation between hatchability on fertile egg and chicks not pipped, dead in germ \& dead in shell was negative and significant $(\mathrm{p}<0.01)$. The chicks not pipped was positively and significantly correlated with dead in germ and dead in shell $(\mathrm{p}<0.01)$. Dead in germ was positively correlated with dead in shell and the correlation was not significant. 
Table 8. Correlations among different hatchability traits of the eggs hatched in the clay box

\begin{tabular}{|c|c|c|c|c|c|c|}
\hline Parameters & $\begin{array}{c}\text { Fertility } \\
\%\end{array}$ & $\begin{array}{c}\text { Hatchability } \\
\text { on total egg } \\
\text { set } \%\end{array}$ & $\begin{array}{c}\text { Hatchability } \\
\text { on fertile eggs } \\
\%\end{array}$ & $\begin{array}{l}\text { Chicks not } \\
\text { pipped \% }\end{array}$ & $\begin{array}{l}\text { Dead in } \\
\text { germ \% }\end{array}$ & $\begin{array}{l}\text { Dead in } \\
\text { shell \% }\end{array}$ \\
\hline Fertility $\%$ & 1.000 & & & & & \\
\hline $\begin{array}{l}\text { Hatchability on total } \\
\text { egg set } \%\end{array}$ & -0.061 & 1.000 & & & & \\
\hline $\begin{array}{l}\text { Hatchability on } \\
\text { fertile eggs \% }\end{array}$ & -0.397 & $0.940^{* *}$ & 1.000 & & & \\
\hline Chicks not pipped \% & 0.397 & $-0.940^{* *}$ & $-1.000^{* *}$ & 1.000 & & \\
\hline Dead in germ \% & 0.233 & $-0.856^{* *}$ & $-0.873^{* *}$ & $0.873^{* *}$ & 1.000 & \\
\hline Dead in shell \% & 0.457 & $-0.724^{*}$ & $-0.815^{* *}$ & $0.815^{* *}$ & 0.429 & 1.000 \\
\hline
\end{tabular}

** Correlation is significant at the 0.01 level, * Correlation is significant at the 0.05 level

Correlations among different hatchability traits of the eggs hatched in the bamboo basket

Correlations among different hatchability traits of the eggs hatched in the bamboo basket are shown in the Table 9. Negative and non-significant correlations were found between fertility and hatchability both on total eggs set and fertile eggs. But the fertility was positively and non-significantly correlated with chicks not pipped, dead in germ \& dead in shell. Hatchability on total egg set was positively and significantly correlated with hatchability on fertile egg $(\mathrm{p}<0.01)$. Again hatchability on total egg set was negatively and significantly correlated with chicks not pipped $(p<0.01)$, dead in germ $(p<0.05) \&$ dead in shell $(\mathrm{p}<0.01)$. The correlation between hatchability on fertile egg and chicks not pipped, dead in germ $(\mathrm{P}<0.05)$ \& dead in shell was negative and significant $(\mathrm{p}<0.01)$. Chicks not pipped was positively and significantly correlated with dead in germ $(p<0.05)$ and dead in shell $(\mathrm{p}<0.01)$. The correlated between dead in germ and dead in shell was positive and not significant.

Table 9. Correlations among different hatchability traits of the eggs hatched in the bamboo basket

\begin{tabular}{l|c|c|c|c|c|c}
\hline \multicolumn{1}{c|}{ Parameters } & Fertility \% & $\begin{array}{c}\text { Hatchability } \\
\text { on total egg } \\
\text { set } \%\end{array}$ & $\begin{array}{c}\text { Hatchability } \\
\text { on fertile } \\
\text { eggs } \%\end{array}$ & $\begin{array}{c}\text { Chicks not } \\
\text { pipped } \%\end{array}$ & $\begin{array}{c}\text { Dead in } \\
\text { germ \% }\end{array}$ & $\begin{array}{c}\text { Dead } \\
\text { in shell } \\
\%\end{array}$ \\
\hline $\begin{array}{l}\text { Fertility \% } \\
\text { Hatchability on total egg } \\
\text { set \% }\end{array}$ & 1.000 & & & & & \\
Hatchability on fertile & -0.184 & 1.000 & & & \\
eggs \% & -0.303 & $0.970^{* *}$ & 1.000 & & & \\
Chicks not pipped \% & 0.307 & $-0.970^{* *}$ & $-1.000^{* *}$ & 1.000 & \\
Dead in germ \% & 0.289 & $-0.633^{*}$ & $-0.725^{*}$ & $0.714^{*}$ & 1.000 & \\
Dead in shell \% & 0.250 & $-0.934^{* *}$ & $-0.924^{* *}$ & $0.930^{* *}$ & 0.407 & 1.000 \\
\hline
\end{tabular}

** Correlation is significant at the 0.01 level, * Correlation is significant at the 0.05 level 


\section{DISCUSSION}

The results on fertility showed that the fertility was not influenced by the types and size of brooding box. This result agrees with the finding of Islam (2003). He found that fertility had no significant effect on increasing or decreasing egg space under broody hen. He found average percentage of fertility of $84.4,83.0,92.0$ and $93.4 \%$ by incubating 8,11 , 14 and 17 eggs per broody hen respectively. Kumar and Acharya, (1976) found fertility for Deshi $90.76-93.12 \%$ which are more or less similar to present study. The hatchability was not significantly affected by types of brooding box made of clay and bamboo basket for all three sizes. This result agrees with Islam (2003) who stated that hatchability were $86.8,85.8,87.4$ and $87.2 \%$ while incubating $8,11,14$ and 17 eggs per box. This result also agrees with Roy et al. (2004) who found $92.4 \%$ hatchability by incubating 18 eggs per broody hen. Sarker et al. (2003) explained that variation in hatchability occurred due to Season, fertility, egg holding period, management of egg during hatching period etc. According to them hatchability was not or little affected by types and sizes of brooding box. As dead in germ was not significantly differ with types and sizes of brooding boxes it can be explained that dead in germ may be more influenced by genetic, environment and management. Such result agrees with Khalil (1960) who stated that embryonic mortality in Fayoumi eggs were 6.1, 2.7 and 14\% during 3 weeks of incubation.The highest percentage of dead-in-shell was recorded in small size box made of bamboo $(18.70 \%)$ followed by small size of clay box $(10.08 \%)$, medium size clay $(5.0 \%)$, medium size bamboo (3.70\%) and large size clay and bamboo box (0.0\%). The higher percentage of dead-in-shell in the small size of bamboo box and small size of clay box $(10.08 \%)$ might be due to lack of optimum conditions of temperature and relative humidity during the incubation period. The present study observed non-significant negative correlations between fertility and hatchability on fertile eggs for both clay and bamboo type boxes.

\section{CONCLUSION}

Hatchability of eggs of Deshi chicken incubated by broody hen can be affected by size of brooding box made of or bamboo basket. The materials have a little or no effect on hatching parameters. The study has shown that hatchability increased with the increasing size of the brooding box. Chicks not pipped, dead in germ and dead in shell were increased with decreasing box size of both clay and bamboo box.

Finally it is concluded from the experiment that the hatchability of Deshi chicken eggs incubated by broody hen can be affected by both materials and size of brooding box. The study showed that the hatchability increased upto a certain level in case of size of the box and clay box gives more hatchability than bamboo basket in case of type of the box. It is very difficult to get the actual result because total number of broody hens was very few and this also needs large number of broody hens. 


\section{REFERENCES}

Bulbul, S. M., Davis, C. H., Preston, T. R., Haque, M. and Sadullah, M. 1983. More protein for the undernourished through a village poultry project. Proceeding of Maximum livestock production from minimum land, held at Bangladesh Agricultural University, Mymensingh.

Farooq, M., Shoukat, K., Asrar, M., Mussawar, S., Durrani, F. R., Asghar, A. and Faisal, S. 2000. Impact of Female Livestock Extension Workers (FLEWs) on rural household chicken. Agril. Res. Rev. 53 : 6,97-104

Haque, M. E., Hamid, M. A., Howlider, M. A. R. and Huque, Q. M. E. 1991. Performance of native chicks and hens reared together or separately under rural conditions of Bangladesh. Bang. Vet., $8: 11-13$.

Haque, Q. M. E., Haque, M. E. and Ragor, E. M. 1990. The effect of chick separation on the productivity of the hen and chick. Asian Austra. J. Anim. Sci., 3(2) :121-123.

Islam, M. A. 2003. Rural Poultry Production: Incubating Capacity of Broody Hens and Chick Performance, Department of Animal Science and Animal Health and Network for Smallholder Poultry Development, the Royal Veterinary and Agricultural University, Bulowsvej 17, 1870 Fredriksberg C., Denmark and Department of Poultry Science, Bangladesh Agricultural University, Mymensingh. Bangladesh.

Kalita, N. 1994. Effects of egg weight storage period and position of egg on hatchability. Indian J. Poult., 29(30) : 281-283.

Khan, A. G. 1983. Improvement of Deshi bird (Part-2). Poult. Adv., 16 : 67-68.

Kumar, J. and Acharya, R. M. 1976. Fertility and hatchability of indigenous and exotic breeds of chickens. Harlan Agricultural University. J. Res. 5(2) : 188-193.

Latif, M.A. (1999). Effect of crossing on fertility and hatchability of Fayoumi chickens. Poult. Sci., 41 : 1707-1712.

Roy, B. C., Ranvig, H., Chowdhury, S. D., Rashid, M. M. and Faruque, M. R. 2004. Production of day-old chicks from crossbred chicken eggs by broody hens, rice husk incubator and electric incubator, and their rearing up to 6 weeks. Gen Comp Endocrinol. 3(2) : 52-53. 